\title{
Evaluation of Water Sorption-solubility and Surface Roughness of Different Bulk Fill Composite Resins
}

\author{
Farklı Bulk Fill Kompozitlerin Su Emilimi, Çözünürlük ve Yüzey \\ Pürüzlülüklerinin Değerlendirilmesi
}

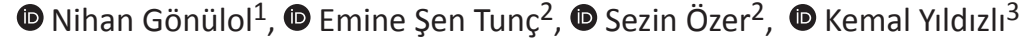 \\ ${ }^{1}$ Ondokuz Mayıs University Faculty of Dentistry, Department of Restorative Dentistry, Samsun, Turkey \\ ${ }^{2}$ Ondokuz Mayıs Üniversitesi Faculty of Dentistry, Department of Pedodontics, Samsun, Turkey \\ ${ }^{3}$ Ondokuz Mayıs Üniversitesi Faculty of Engineering, Department of Mechanical Engineering, Samsun, Turkey
}

Keywords

Resin composite, solubility, sorption, surface roughness

\section{Anahtar Kelimeler \\ Kompozit rezin, çözünürlük, emilim, yüzey pürüzlülüğü}

Received/Geliş Tarihi : 08.02.2018

Accepted/Kabul Tarihi : 19.04.2018

doi:10.4274/meandros.galenos.2018.86548

Address for Correspondence/Yazışma Adresi: Nihan Gönülol

Ondokuz Mayıs University Faculty of Dentistry, Department of Restorative Dentistry, Samsun, Turkey

E-mail : nihan.gonulol@omu.edu.tr

ORCID ID: orcid.org/0000-0002-7046-7154

(C) Meandros Medical and Dental Journal, Published by Galenos Publishing House.

This is article distributed under the terms of the Creative Commons Attribution NonCommercial 4.0 International Licence (CC BY-NC 4.0).

\begin{abstract}
Objective: This study aimed to investigate and compare the water sorption (WS), solubility (SO) and surface roughness (SR) of four bulk fill resin-based composites (RBCs), a conventional flowable RBC and a conventional hybrid RBC.

Materials and Methods: Disc-shaped specimens of 3 low-viscosity bulk fill RBCs (SureFil SDR flow, X-tra base, Filtek Bulk Fill flow), 1 high-viscosity bulk fill RBC (Tetric EvoCream Bulk Fill), 1 conventional low-viscosity flowable RBC (Filtek Ultimate flow) and 1 conventional hybrid RBC (Filtek Z250) $(n=10)$ were prepared and immersed in distilled water for 28 days. Upon removal, specimens were weighed using an electronic scale to determine WS and SO based on weight gain/loss, and surface profilometry was performed to determine SR. Data were analyzed using one-way ANOVA and Tukey's post-hoc tests $(\mathrm{p}=0.05)$.

Results: WS and S0 showed significant, positive correlations ( $r=0.612 ; p<0.001)$, and both varied significantly among the materials, with WS and SO values of both high-filled and low-filled bulk fill RBCs lower than their conventional counterparts. Moreover, SR values of both bulk and conventional flowable low-fill RBCs were significantly lower in comparison to the high-fill RBCs $(p<0.05)$.

Conclusion: WS, SO and SR of RBCs are material-dependent and highly affected by filler loading and resin matrix composition. Bulk fill RBCs can be used in a large variety of clinical situations in line with the manufacturers' recommendations.
\end{abstract}

Öz

Amaç: Bu çalışmanın amacı dört farklı bulk fill kompozit rezin ile bir adet geleneksel akışkan kompozit ve bir adet geleneksel hibrit kompozitin su emilimi, çözünürlük ve yüzey pürüzlülüğü değerlerini karşılaştırmalı olarak incelemektir.

Gereç ve Yöntemler: Üç adet düşük viskoziteli bulk fill kompozit (SureFil SDR flow, X-tra base, Filtek Bulk Fill flow), bir adet yüksek viskoziteli bulk fill kompozit (Tetric EvoCream Bulk Fill), bir adet geleneksel düşük viskoziteli akışkan kompozit (Filtek Ultimate flow) ve bir adet geleneksel hibrit kompozit (Filtek Z250) kullanılarak disk şeklinde örnekler hazırlanıp distile suda 28 gün bekletilmiştir $(n=10)$. Örnekler elektronik bir terazide tartılarak kütle kazanım ve kayıp değerlerine göre su emilimi ve çözünürlük değerleri hesaplanmıştır. Daha sonra yüzey pürüzlülüğü ölçümü için profilometre cihazı kullanılmıştır. Elde edilen veriler tek yönlü ANOVA ve Tukey post-hoc testleri ile analiz edilmiştir $(p=0,05)$. 
Bulgular: Su emilimi ve çözünürlük değerleri arasında pozitif korelasyon tespit edilmiştir $(r=0,612 ; p<0,001)$, her iki parametre de materyaller arasında belirgin farklılık göstermiştir. Hem düşük hem de yüksek viskoziteli bulk fill kompozitler geleneksellerine kıyasla daha düşük su emilimi ve çözünürlük değerleri göstermiştir. Yüzey pürüzlülüğü açısından ise hem geleneksel hem de bulk fil akışkan kompozler, yüksek dolduruculara göre belirgin şeklide daha düşük pürüzlülük göstermiştir $(p<0,05)$.

Sonuç: Su emilimi, çözünürlük ve yüzey pürüzlülüğü değerleri materyale bağlı özelliklerdir ve rezin matriksin yapısından ve doldurucu oranından önemli derecede etkilenirler. Üretici önerileri doğrultusunda bulk fill kompozitler klinikte geniş bir kullanım alanına sahiptirler.

\section{Introduction}

As a result of constant efforts by the industry to improve the properties of dental materials, several innovative restorative materials have been introduced for use in posterior dental restorations, including a new class of resin-based composite (RBC) materials known as "bulk fill RBCs"(1). Manufacturers of bulk fill composites claim that polymerization shrinkage stress has been reduced and depth of cure improved sufficiently to allow for placement of these materials in layers of up to $4 \mathrm{~mm}$. The improvements in material characteristics have been achieved through various strategies - e.g. using macrofillers to increase material translucency, incorporating particles with a low elastic modulus and otherwise modifying resin composition, as well as using alternative photoinitiator systems $(2,3)$. In contrast to the first versions of bulk fill materials, which had low viscosity and required an additional, final layer of conventional RBC, the recently introduced bulk fill RBCs have a higher viscosity and don't require capping with conventional RBCs (4). Most low-viscosity, flowable bulk fill RBCs are indicated by their manufacturers for use as either a liner or base in class 1 and 2 cavities (1). In addition, some flowable bulk fill RBCs are indicated for use in class 3 and 5 cavities as well as in the restoration of minimally invasive cavity preparations and as pitand-fissure sealants $(5,6)$. High-viscosity bulk fill RBCs are indicated for restorations in the posterior region (classes 1 and 2, including the replacement of individual cusps), class 5 restorations and reconstructive buildup (3). Regardless of their properties, all restorative materials are subjected directly to saliva and other altering conditions in the oral environment, making water sorption (WS), water solubility (SO) and surface roughness (SR) important parameters in determining their clinical longevity (7-9). This study measured the WS, SO and SR of 4 bulk fill RBCs and compared them to those of a conventional flowable RBC and a conventional hybrid RBC. The null hypotheses were that:

1. WS, SO and SR of the tested bulk fill RBCS would not differ from those of their conventional counterparts; and

2. WS, SO and SR properties of low-fill RBCs would not differ from those of high-fill RBCs.

\section{Materials and Methods}

\section{Test Materials}

The study was conducted with 6 commercially available RBCs, including 3 low-viscosity flowable bulk fill RBCs, 1 high-viscosity bulk fill RBC, 1 conventional low-viscosity flowable RBC and 1 conventional highviscosity hybrid RBC. Material formulations and manufacturers are listed in Table 1.

\section{Water Sorption and Solubility}

Specimens ( $n=10$ per group) were prepared using $2 \mathrm{~mm}$ depth $\times 10 \mathrm{~mm}$ diameter teflon molds. Molds were filled with composite, placed between two glass microscope slides, each about $1 \mathrm{~mm}$ thick, and pressed by hand to extrude excess material. A light emitting diode light-curing unit, (Elipar Free Light II, 3M/ESPE, St. Paul, MN, USA) was used to deliver $1.200 \mathrm{~mW} / \mathrm{cm}^{2}$ irradiation to each specimen. Light intensity was checked between each application using a calibrated radiometer. Specimens were irradiated from both the top and bottom surfaces for $20 \mathrm{~s}$ each, with the light tip $-9.5 \mathrm{~mm}$ diameter - in direct contact with the microscope slides. After curing, the specimens were released from the molds, extruded material was removed using abrasive paper (Phoenix Beta, Buehler, Germany), and debris was cleared away using a dust blower. Specimens were placed in a vacuum desiccator and dried at $37 \pm 1{ }^{\circ} \mathrm{C}$ for 22 hours, transferred to a second desiccator and further dried at $23 \pm 1{ }^{\circ} \mathrm{C}$ for 2 hours, and then weighed to an accuracy of $0.0001 \mathrm{~g}$, using a digital scale (Precisa XB 220 A, Zurich, Switzerland). The process was repeated 
until a constant mass value was obtained (i.e. mass change of $\leq 0.1$ ) on the display of the scale and recorded as " $m_{1}$ ". Specimens were then immersed in $10 \mathrm{~mL}$ distilled water in individual containers at $37 \pm 1$ ${ }^{\circ} \mathrm{C}$ for 28 days, removed, gently dried with absorbent paper and weighed again to obtain to evaluate the weight after immersion and recorded as " $m_{2}$ ". Using the same protocol described above, specimens were reconditioned in desiccators until a constant mass was obtained again to evaluate the mass loss after immersion and recorded as " $\mathrm{m}_{3}$ ". Percentages of WS and SO were calculated for each specimen according to the following equations: WS $\left.=100 \times\left(m_{2}-m_{1}\right) / m_{1}\right)$, SO $\left.=100 \times\left(m_{1}-m_{3}\right) / m_{1}\right)$.
An additional 10 specimens per group were prepared and polymerized as described above. Following polymerization, specimens were stored in distilled water at $37{ }^{\circ} \mathrm{C}$ for $24 \mathrm{~h}$, removed and finished/polished using a series of aluminum oxide discs (Sof-Lex, 3M ESPE, St. Paul, MN, USA) for $15 \mathrm{~s}$ per disc (coarse medium, fine, superfine) in the same direction without water cooling. All preparations were performed by a single investigator. Polished specimens were rinsed in distilled water and allowed to dry again for $24 \mathrm{~h}$ in the room temperature $\left(23^{\circ} \mathrm{C}\right)$ before the average SR measurement. Roughness measurements were taken at 3 different locations per specimen from the top surfaces using a surface profilometer

\begin{tabular}{|l|l|l|l|}
\hline \multicolumn{2}{|l|}{ Table 1. Materials used in the present study } & Resin system & Filler (wt\%), (vol\%) \\
\hline $\begin{array}{l}\text { Product } \\
\text { Filtek-bulk fill flowable, 3M ESPE, Germany }\end{array}$ & Low viscosity bulk fill & $\begin{array}{l}\text { Bis-GMA, UDMA, Bis-EMA, TEGDMA, } \\
\text { procrylat resin }\end{array}$ & $64.5 \%, 42.5 \%$ \\
\hline $\begin{array}{l}\text { SureFil SDR flow, Dentsply Caulk, Milford, } \\
\text { DE, USA }\end{array}$ & Low viscosity bulk fill & Modified UDMA, Bis-EMA, TEGDMA & $68 \%, 44 \%$ \\
\hline X-tra base, VOCO, Germany & Low viscosity bulk fill & Bis-EMA, EBPADA & $75 \%$, NA \\
\hline $\begin{array}{l}\text { Tetric EvoCeram bulk fill, Ivoclar Vivadent, } \\
\text { Schaan, Liechtenstein }\end{array}$ & High viscosity bulk fill & Bis-GMA, UDMA, Bis-EMA, & $77 \%, 60-61 \%$ \\
\hline $\begin{array}{l}\text { Filtek }{ }^{\text {TM }} \text { Supreme XTE, 3 M ESPE, Germany } \\
\text { Filtek Z 250, 3 M ESPE GmbH, Germany }\end{array}$ & $\begin{array}{l}\text { Conventional flowable } \\
\text { RBC }\end{array}$ & $\begin{array}{l}\text { Bis-GMA, TEGDMA, Bis-EMA, } \\
\text { procrylat resin }\end{array}$ & $65 \%, 55 \%$ \\
\hline $\begin{array}{l}\text { NA: Stands for not available, UDMA: Urethane dimethacrylate, Bis-EMA: Bisphenol A ethoxylate dimethacrylate, TEGDMA: Triethylene glycol } \\
\text { dimethacrylate, Bis-GMA: Bisphenol A glycidyl dimethacrylate, EBPADA: Ethoxylated bisphenolAdiacrylate, RBC: Resin-based composites }\end{array}$ & UDMA, Bis-GMA, Bis-EMA, TEGDMA & $82 \%$, NA \\
\hline
\end{tabular}

\begin{tabular}{|c|c|c|c|}
\hline Material & WS (\%) & so (\%) & $S R(R a, \mu m)$ \\
\hline Filtek Bulk fill flowable & $1.32 \pm 0.21^{\mathrm{BC}}$ & $0.08 \pm 0.03^{c}$ & $0.07 \pm 0.02^{x}$ \\
\hline SureFil SDR flow & $1.03 \pm 0.34^{\mathrm{AB}}$ & $0.03 \pm 0.01^{b}$ & $0.08 \pm 0.03^{x}$ \\
\hline X-tra base & $0.81 \pm 0.28^{A}$ & $-0.07 \pm 0.03^{a}$ & $0.07 \pm 0.02^{x}$ \\
\hline Tetric EvoCeram bulk fill & $1.07 \pm 0.14^{\mathrm{AB}}$ & $-0.05 \pm 0.01^{a}$ & $0.38 \pm 0.17^{y}$ \\
\hline Filtek $^{\mathrm{TM}}$ supreme XTE & $1.41 \pm 0.17^{c}$ & $0.12 \pm 0.04^{c}$ & $0.05 \pm 0.02^{x}$ \\
\hline Filtek $^{\mathrm{TM}} \mathrm{Z} 250$ & $1.24 \pm 0.23^{\mathrm{BC}}$ & $0.12 \pm 0.04^{c}$ & $0.32 \pm 0.12^{y}$ \\
\hline
\end{tabular}


(Mitutoyo SJ-400, Mitutoyo, Tokyo, Japan) with a speed of $0.1 \mathrm{~mm} / \mathrm{s}$, a $0.25 \mathrm{~mm}$ cutoff value and a 2 $\mathrm{mm}$ tracing length. SR values were calculated as the average of the 3 readings and recorded as "Ra" $(\mu \mathrm{m})$.

\section{Statistical Analysis}

All statistical analysis was performed using SPSS for Windows, Version 12.0.1 (SPSS Inc, Chicago, IL, USA). Shapiro-Wilk's tests were performed and showed normality of distribution for all groups. Thus, data were compared using 1-way ANOVA followed by Tukey honestly significant difference and Tamhane's T2 post-hoc tests. Pearson correlation coefficients were calculated to analyze the correlation between WS and SO for each test material during $28 \mathrm{~d}$ water immersion. The level of significance was set at at 0.05 .

\section{Results}

Means and standard deviations for the groups are presented in Table 2. The Pearson correlation coefficient analysis showed a positive, significant, correlation between WS and SO ( $r=0.612 ; p<0.001)$. $X$-tra base had the lowest WS value $(0.81 \pm 0.28)$, and Filtek ${ }^{\mathrm{TM}}$ Supreme XTE had the highest WS value (1.41 \pm 0.17$)$. Differences in WS between X-tra base, SureFil SDR flow and Tetric EvoCeram Bulk Fill and between Filtek ${ }^{\mathrm{TM}}$ Supreme XTE, Filtek Bulk Fill Flowable and Filtek $^{\mathrm{TM}} \mathrm{Z} 250$ were not statistically significant ( $p>0.05)$.

SO values varied significantly among the groups $(p<0.05)$. The lowest SO values were detected in the $\mathrm{X}$-tra base $(-0.07 \pm 0.03)$ and Tetric EvoCeram bulk fill $(-0.05 \pm 0.01)$ groups $(p<0.05)$. The highest SO values were observed in the Filtek ${ }^{\mathrm{TM}}$ Supreme XTE $(0.12 \pm 0.04)$ and Filtek ${ }^{\mathrm{TM}} \mathrm{Z250}(0.12 \pm 0.04)$ groups, but the differences in values among Filtek $^{\mathrm{TM}}$ Supreme XTE, Filtek $^{\mathrm{TM}} \mathrm{Z} 250$ and Filtek Bulk Fill flowable group were not statistically significant ( $p>0.05$ ).

$S R$ values also varied significantly among the groups $(p<0.05)$, as follows: Filtek ${ }^{\mathrm{TM}}$ Supreme XTE<Filtek Bulk Fill flowable $=X$-tra base $<$ SureFil SDR flow $<$ Filtek $^{\text {TM }}$ Z250<Tetric EvoCeram bulk fill.

\section{Discussion}

According to the study findings, WS, SO and SR values for some of the tested bulk fill RBCs were similar to those of their conventional counterparts; therefore, the first null hypothesis was partially accepted. Furthermore, viscosity had an effect on the
SR of the bulk fill RBCs, but had no effect on their WS or SO; therefore, the second null hypothesis was also partially accepted.

The clinical performance of RBCs is dependent upon material characteristics as well as clinician proficiency. Until the last few decades, incremental layering had long been accepted as the standard technique for resin-composite cavity preparations (10). However, this technique has several drawbacks, namely the possibility of voids, contamination, or bond-failure between composite layers as well as the relatively extensive time required to place and polymerize each layer. In light of several recent studies suggesting that fewer increments and even bulk filling could be just as successful as the traditional layered approach $(11,12)$, several manufacturers have developed posterior "bulk fill composite resins" that claim to have enhanced curing, shrinkage and other physical properties $(2,3,5,6)$. Although various studies have been conducted that examine bulk fill RBCs, particularly in terms of polymerization (1,13-15), there is little information available regarding the WS, SO and SR of bulk fill RBCs.

WS and SO are important properties in assessing the clinical durability of dental restorative materials. According to ISO 4049:2009, WS is assessed by immersing dried specimens in distilled water for a certain period of time and by determining the amount of absorbed water by weight and the SO should be determined by weighing these specimens after drying them once again to constant weight (16). WS is a diffusion-controlled process that may to a certain extent reduce the polymerization shrinkage stress of RBCs (17), but may also result in chemical degradation of the material, leading to drawbacks such as filler-polymer matrix debonding and residual monomer release, and to mechanical degradation, leading to reductions in RBC restoration longevity (7) and potential allergic reactions in some patients (18). WS of RBC is affected mainly by material hydrophilicity and cross-linking of the network structure. Filler material, grain size, volume fraction and dispersion within the matrix as well as properties of the fillermatrix interface also play a role in the amount of solvent uptake during exposure (19-21). This study found the low-viscosity bulk fill composites X-tra base and Surefil SDR flow had significantly lower WS values when compared to their conventional counterpart. 
This could be attributed to the higher filler-loading content of the bulk fill composites, given that an increase in filler ratio (by weight) entails a smaller polymeric matrix and hence a decrease in WS $(21,22)$. The similar WS values of Filtek Bulk Fill Flowable and Filtek $^{\text {TM }}$ Supreme XTE can be explained by the similar filler loading and resin contents of the two materials, as noted by Alshali et al (21). In contrast to the lowviscosity RBCs tested, no significant differences in WS values were found between the high-viscosity bulk fill RBC TetricEvoCeram bulk fill and the high-viscosity conventional RBC Filtek ${ }^{\mathrm{TM}} \mathrm{Z250}$ ( $\left.p>0.05\right)$. Although Filtek $^{\mathrm{TM}} \mathrm{Z250}$ has higher filler load than Tetric EvoCeram bulk fill; the fillers used in Filtek ${ }^{\mathrm{TM}} \mathrm{Z} 250$ are unsilanated, this could be expected to weaken the filler-matrix interface (21).

SO and WS are expected to show a correlation, since a solvent needs to penetrate a material in order for unreacted components to leach out. At the same time, conversion and cross-linking density play a major role in the relationship between sorption and SO (23). In fact, this study found correlations between WS and SO values for all RBCs tested $(r=0.612)$. Thus, the same factors described above with regard to WS are also able to explain the findings of the present study with regard to SO. This study found negative SO values for X-tra base and Tetric EvoCeram bulk fill, indicating a reduction in the final volume when compared to the initial volume-which does not mean that the materials exhibited no SO, but simply that the amount of SO was less than the amount of WS of the materials. The negative values may mask the actual properties of the materials tested with regard to SO (24). Previous studies have also reported negative SO values for Tetric EvoCeram bulk fill $(21,25)$. It has been suggested that this finding is related to incomplete dehydration and the formation of metal hydroxides within the RBC (21). SR is an important property that affects the appearance of $\mathrm{RBC}$ restorations. Profilometry using a contact stylus and determination of the Ra parameter has been a common method of quantitatively evaluating the SR of dental materials. A rough surface leads to increases in the accumulation of dental biofilm, residues and dyes, causing gingival irritation and a risk of secondary caries, and also diminishing restoration gloss, resulting in discoloration (26). The SR of RBCs is influenced by several material factors, including the type, shape, size and distribution of inorganic fillers. This study found no difference in the SR values of bulk fill RBCs when compared to their conventional counterparts $(p>0.05)$. However, the high fill RBCs (Tetric EvoCeram bulk fill and Filtek ${ }^{\mathrm{TM}}$ Z250) had significantly higher SR values than the low-fill RBCs. An earlier study also reported highfill RBCs to have higher SR values than low-fill RBCs (27). Moreover, previous studies have suggested that SR decreases in line with decreases in filler size (28) and increases in filler content (29). The nano-fill RBC Filtek Supreme XTE is characterized by a low fillerparticle size and a low filler load, which could explain why it yielded the lowest Ra values of all the RBCs tested in this study. Roughness values of $>0.2 \mu \mathrm{m}$ can increase plaque accumulation, secondary caries risk and periodontal inflammation. In the present study, SR values of the high-fill RBCs Tetric EvoCeram bulk fill and Filtek ${ }^{\mathrm{TM}} \mathrm{Z} 250$ were $0.38 \mu \mathrm{m}$ and $0.32 \mu \mathrm{m}$, respectively which are above clinically acceptable values. Previous studies have also reported high Ra values for Filtek ${ }^{\mathrm{TM}} \mathrm{Z} 250(30,31)$.

\section{Conclusion}

Dental practitioners need to keep abreast of the rapid developments in dental materials in terms of technical properties and clinical performance. Within the limitations of this in vitro study, bulk fill materials had WS, SO and SR values that were better or equal to their conventional counterparts, suggesting that they can, in fact, be used in the large variety of clinical situations recommended by their manufacturers.

\section{Ethics}

Ethics Committee Approval: It was not taken.

Informed Consent: It was not taken.

Peer-review: Externally peer-reviewed.

\section{Authorship Contributions}

Design: N.G., Data Collection or Processing: N.G., E.Ş.T., Analysis or Interpretation: S.Ö., Literature Search: S.Ö., K.Y., N.G., Writing: N.G., E.Ş.T.

Conflict of Interest: No conflict of interest was declared by the authors.

Financial Disclosure: The authors declared that this study received no financial support.

\section{References}

1. Czasch P, llie N. In vitro comparison of mechanical properties and degree of cure of bulk fill composites. Clin Oral Investig 2013; 17: 227-35. 
2. Dentsply (2011) SDR Scientific Compendium. Retrieved online August 1, 2016 from: http://www.dentsply.de/bausteine. net/f/8883/SCSDRDeTrey110815E.pdf?fd=2.

3. Ivoclar Vivadent (2013) Tetric EvoCeram Bulk Fill Scientific Documentation. Retrieved online August 1, 2016 from: http:// www.ivoclarvivadent.us/en-us/composites/restorativematerials/tetric-evoceram-bulk fill.

4. Ilie N, Bucuta S, Draenert M. Bulk fill resin-based composites: an in vitro assessment of their mechanical performance. Oper Dent 2013; 38: 618-25.

5. VOCO GmbH (2013) x-tra base. Retrieved online August 1, 2016 from http://www.voco.com/en/product/x-tra_base/index.html.

6. 3M ESPE (2012) Filtek Bulk Fill Flowable Restorative Technical Product Profile. Retrieved online August 1, 2016 from:http:// multimedia.3m.com/mws/media/7923210/filtek-bulk fillflowable-restorative-technical-product-profile.pdf.

7. Söderholm KJ, Mukherjee R, Longmate J. Filler leachability of composites stored in distilled water or artificial saliva. J Dent Res 1996; 75: 1692-9.

8. Bollen CM, Lambrechts P, Quirynen M. Comparison of surface roughness of oral hard materials to the threshold surface roughness for bacterial plaque retention: a review of the literature. Dent Mater 1997; 13: 258-69.

9. Sideridou I, Tserki V, Papanastasiou G . Study of water sorption, solubility and modulus of elasticity of light-cured dimethacrylatebased dental resins. Biomaterials 2003; 24: 655-65.

10. Kwon Y, Ferracane J, Lee IB. Effect of layering methods, composite type, and flowable liner on the polymerization shrinkage stress of light cured composites. Dent Mater 2012; 28: 801-9.

11. Abbas G, Fleming GJP, Harrington E, Shortall AC, Burke FJ. Cuspal movement and microleakage in premolar teeth restored with a packable composite cured in bulk or in increments. J Dent 2003; 31: 437-44.

12. Sarrett DC. Clinical challenges and the relevance of materials testing for posterior composite restorations. Dent Mater 2005; 21: 9-20.

13. Al-Ahdal K, Ilie N, Silikas N, Watts DC. Polymerization kinetics and impact of post polymerization on the degree of conversion of bulk fill resin-composite at clinically relevant depth. Dent Mater 2015; 31: 1207-13.

14. Han SH, Sadr A, Tagami J, Park SH. Internal adaptation of resin composites at two configurations: Influence of polymerization shrinkage and stress. Dent Mater 2016; 32: 1085-94.

15. Al Sunbul H, Silikas N, Watts DC. Polymerization shrinkage kinetics and shrinkage-stress in dental resin-composites. Dent Mater 2016; 32: 998-1006.

16. International Standard ISO 4049:2009. Dentistry - polymerbased restorative materials.
17. Feilzer AJ, de Gee AJ, Davidson CL. Relaxation of polymerization contraction shear stress by hygroscopic expansion. J Dent Res 1990; 69: 36-9.

18. Ferracane JL. Hygroscopic and hydrolytic effects in dental polymer networks. Dent Mater 2006; 22: 211-22.

19. Ferracane JL, Condon JR. Rate of elution of leachable components from composite. Dent Mater 1990; 6: 282-7.

20. Zhang $Y, X u$ J. Effect of immersion in various media on the sorption, solubility, elution of unreacted monomers, and flexural properties of two model dental composite compositions. J Mater Sci Mater Med 2008; 19: 2477-83.

21. Alshali RZ, Salim NA, Satterthwaite JD, Silikas N. Long-term sorption and solubility of bulk fill and conventional resincomposites in water and artificial saliva. J Dent 2015; 43: 1511-8.

22. Oysaed H, Ruyter IE. Water sorption and filler characteristics of composites for use in posterior teeth. J Dent Res 1986; 65: 13158.

23. Floyd CJ, Dickens SH. Network structure of Bis-GMA- and UDMAbased resin systems. Dent Mater 2006; 22: 1143-9.

24. Fabre HS, Fabre S, Cefaly DF, de Oliveira Carrilho MR, Garcia FC, Wang L.Water sorption and solubility of dentin bonding agents light-cured with different light sources. J Dent 2007; 35: 253-8.

25. Al Sunbul H, Silikas N, Watts DC. Resin-based composites show similar kinetic profiles for dimensional change and recovery with solvent storage. Dent Mater 2015; 31: e201-17.

26. Yap AU, Lye KW, Sau CW. Surface characteristics of tooth-colored restoratives polished utilizing different polishing systems. Oper Dent 1997; 22: 260-5.

27. Ozel E, Korkmaz Y, Attar N, Karabulut E. Effect of one-step polishing systems on surface roughness of different flowable restorative materials. Dent Mater J 2008; 27: 755-64.

28. Jung $M$, Eichelberger $K$, Klimek J. Surface geometry of four nanofiller and one hybrid composite after one step and multiple step polishing. Oper Dent 2007; 32: 347-55.

29. Janus J, Fauxpoint G, Arntz Y, Pelletier H, Etienne O. Surface roughness and morphology of three nanocomposites after two different polishing treatments by a multitechnique approach. Dent Mater 2010; 26: 416-25.

30. Venturini D, Cenci MS, Demarco FF, Camacho GB, Powers JM. Effect of polishing techniques and time on surface roughness, hardness and microleakage of resin composite restorations. Oper Dent 2006; 31: 11-7.

31. Gönülol N, Yilmaz F. The effects of finishing and polishing techniques on surface roughness and color stability of nanocomposites. J Dent 2012; 40 Suppl 2: e64-70. 